fluid and some well defined violent or criminal behaviour, causation is not proved. Do low concentrations of the metabolite cause the abnormal behaviour or does the abnormal behaviour trigger physiological responses in the body that lower the concentrations? Perhaps there is some third factor - biological, psychological, or environmental-that is the underlying cause of both the low concentrations and abnormal behaviour.

Within the past year Brunner and colleagues have reported an association between a point mutation in the structural gene for monoamine oxidase A in a large Dutch family and aggressive criminal behaviour among many males in that family. ${ }^{9}$ Other single gene conditions are known to result in abnormal behaviour-for example, the symptoms of Wilson disease, which result from accumulation of copper primarily in the liver and brain, can mimic those of schizophrenia. The gene for monoamine oxidase $\mathrm{A}$, however, is the first instance of an altered gene being implicated in specifically criminal aggressive behaviour. As monoamine oxidase $\mathrm{A}$ is involved in serotonin metabolism researchers have suggested that the gene mutation that results in monoamine oxidase A deficiency is related to the low cerebrospinal fluid concentrations of 5-hydroxyindoleacetic acid found in association with criminal behaviour. $^{9}$

Although the defect in the gene for monoamine oxidase $\mathrm{A}$ is likely to be responsible for the learning disabilities and possibly the abnormal behaviours in the Dutch family, there is little prospect that a better understanding of this condition will improve our understanding of criminality. The primary effect of the mutation is learning disability; the aggressive behaviour, which does not appear in all the males with the genetic abnormality, may result from the learning disability and its attendant problems rather than directly from the altered gene. Furthermore, as the authors point out, this genetic defect is extremely rare. Even if its importance in causing criminal behaviour is confirmed it is unlikely to be important in more than a minute proportion of criminals.

The genetic and biochemical studies discussed above found an association between a biological factor and violent criminal behaviour. But a series of adoption studies in which the criminal history of an adopted male was compared with the criminal history of both his biological and his adoptive fathers found that genetic influences were significant in cases of property crime but not in cases of violent crime. ${ }^{10}$ This conclusion is as problematic as finding a genetic basis for violent crime. Adoption studies have their own methodological problems-for example, various social characteristics of the adoptive and biological home environments are correlated, and adoptive parents are generally of higher socioeconomic status than parents in general. ${ }^{11}$ Although researchers try to correct for these complicating factors, the corrections are post hoc.

Although studies of the biological basis of violence interest nearly everyone, currently, research on this topic is far too preliminary to be of use to psychiatrists treating people who are predisposed to or engage in violent and criminal activities. Nevertheless, there have been suggestions that public policy should be informed by the results of these biological studies. Given the extremely tentative nature of their conclusions and the far reaching consequences of labelling people as potential criminals on the basis of some biological marker, an awareness of the limitations of these studies is crucially important.

JOSEPH S ALPER Professor

Department of Chemistry,

University of Massachusetts-Boston,

Boston, MA 02125,

USA

1 Borgaonkar DS, Shah SA. The XYY chromosome male-or syndrome. Prog Med Genet 1974;10:135-222.

2 Christiansen KO. A review of studies of criminality among twins. In: Mednick SA, Christiansen KO, eds. Biosocial bases of criminal behavior. New York: Gardner Press, 1977:45-88.

3 Cloninger CR, Gottesman II. Genetic and environmental factors in antisocial behavior disorders. In: Mednick SA, Moffitt TE, Stack SA, eds. The causes of crime: new biological approaches. New
(n) York: Cambridge, 1987:92-109.

4 Rowe DC. Genetic and environmental components of antisocial behavior: a study of 265 twin pairs. Criminology 1986;24:513-32.

5 Walters GD. A meta-analysis of the gene-crime relationship. Criminology 1992;30:595-613.

6 Carey G. Genetics and violence. In: Reiss AJ Jr, Miczek KA, Roth JA, eds. Understanding and preventing violence. Vol 2. Biobehavioral influences. Washington, DC: National Academy Press, 1994:21-58.

7 Van Praag HM. Serotonergic dysfunction and aggression control. Psychol Med 1991;21:15-9.

8 Kidd KK. Association of disease with genetic markers: deja vu all over again. Am $\mathcal{F}$ Med Genet (Neuropsychiatric Genetics) 1993;48:71-3.

9 Brunner HG, Nelen M, Breakefield XO, Ropers HH, van Oost BA. Abnormal behavior associated with a point mutation in the structural gene for monoamine oxidase A. Science 1993;262:578-80.

10 Brennan PA, Mednick SA. Genetic perspectives on crime. Acta Psychiatr Scand 1993;370(suppl): 19-26.

11 Billings PR, Beckwith J, Alper JS. The genetic analysis of human behavior: a new era? Soc Sci Med 1992;35:227-38.

\title{
Television violence and children
}

\section{Its effects need to be seen in the context of other influences on children's mental health}

Children watch two to three hours' television daily from the age of 3 or earlier, and during childhood they average more time in front of the television set than in the classroom. ${ }^{1}$ Although watching television has positive effects, ${ }^{2}$ attention is usually focused on its negative ones. Some people believe that children may be harmed by watching violence on the screen, ${ }^{34}$ and, although over 1000 research studies have established an association between screen violence and the level of aggressive behaviour in some children and young people, ${ }^{56}$ causation has not been established. Increased aggression may not be the only negative effect. Children may find some of the images frightening and in rare cases develop anxiety and phobic reactions; more commonly they may develop short lived nightmares and other sleep problems. ${ }^{7}$

Television violence may influence children in four ways: making them want to imitate what they see, reducing learnt inhibitions against violent behaviour, desensitising them to violence through repetition, and increasing arousal. ${ }^{1}$ Viewing violence on the screen does not on its own cause violent behaviour. ${ }^{8}$ The most plausible model to explain the association between viewing violence and increased aggression is an interactive one in which viewing and aggression affect each other and, in turn, are stimulated by other related variables.

Aggression as a problem solving behaviour is learnt early in life, is usually learnt well, and is resistant to change. ${ }^{10}$ Individual variation in the level of aggressive behaviour and violence in children, adolescents, and adults depends on many interacting factors, of which media influences are likely to be less important than constitutional, parental, educational, and other environmental influences. Contributing factors include being the victims of violence and bullying and witnessing violence perpetrated against others, especially at home. The emphasis on establishing whether television violence and actual violence are related has resulted in the neglect of these other, more important influences on the development of aggressive behaviour and other effects of 
media images on the mental health of children. ${ }^{11}{ }^{12}$

Children of different ages have very different capacities for understanding media violence, and adults' perceptions of what is violent may not agree with children's. Developmental factors, including the degree of attachment to parenting adults, ability to control aggression, cognitive ability, and moral development are particularly relevant to how children experience, understand, and process media violence..$^{13}$

The advent of videos depicting the mutilation, torture, and dismemberment of humans and the violation and degradation of women has called into question the validity of studies done with more conventional images. ${ }^{4}$ Concern about possible adverse effects led to the Video Recordings Act 1984 and to the penalties for supplying unclassified videos to young people being stiffened in the Criminal Justice and Public Order Act 1994.

Technological advances, including satellite and cable television, interactive computer games, and the information superhighway, give children easier access to a wide range of violent images, with less prospect of effective censorship. The need is therefore to consider how best to protect and educate children. Parents need more objective information about the content of films to supervise their children better. They also need education courses about the media and should participate in decisions about the appropriate classification of films and videos. ${ }^{14}$ Media studies is now a part of the national curriculum for English, albeit a marginal one, and more systematic, coordinated provision of such studies is needed. Training in non-violent methods of resolving conflict is effective in reducing aggression in young children, and these techniques deserve wider promulgation..$^{1015}$

Some people argue that horror films can offer a form of vicarious training in coping with fear and that they are little more than a contemporary form of fairy tale, which explains their popularity. Although most children can learn to distinguish fiction from fact quite early and many enjoy a feeling of fear, which they know will be resolved by a "happy" ending, in fiction, factual violence and horror may be more frightening as the end is unpredictable and uncontrollable. Research findings on this, however, are equivocal and inconsistent (D Buckingham, unpublished literature review).
Children need the help of adults to interpret what they see and to protect them from unsuitable programmes. It is perhaps the children most vulnerable to the effects of viewing violence who are the most likely to see violent programmes or videos and to see them unsupported by adults. Not all parents realise the need for supervision or can exercise it. Doctors doing home visits are more aware than most of how prevalent television sets and video cassette recorders are in children's bedrooms.

In our current state of knowledge, the advice practitioners may wish to give worried parents is that, although frequent, lengthy, and unsupervised viewing of violence and horror is likely to affect the behaviour and mental health of some vulnerable children and young people adversely, occasional viewing is unlikely to harm most children. For the future we need more discussion, informed by findings from well designed empirical research studies, of the characteristics of both the material and the viewer that are associated with an increase in aggressive and disturbed behaviour.

DORA BLACK
Consultant child and adolescent psychiatrist MARTIN NEWMAN

Children's Trauma Clinic,

Royal Free Hospital,

London NW3 2QG

1 Gunter B, McAleer IL Children and television - the one eyed monster? London: Routledge, 1990.

2 Buckingham D. Reading audiences-young people and the media. Manchester: Manchester University Press, 1993 .

3 Barlow G, Hill A, eds. Video violence and children. London: Hodder and Stoughton, 1985.

4 Newson E. Video violence and the protection of children. The Psychologist 1994:7:272-4.

5 Pearl D, Bouthilet L, Lazar J. Television and behavior: ten years of scientific progress and implications for the eighties. Rockville: US Department of Health and Human Services, 1982.

6 Williams TM, ed. The impact of television: a natural experiment. New York: Academic Press, 1986.

7 Melville-Thomas G. Television violence and children. In: Barlow G, Hill A, eds. Video violence and children. London: Hodder and Stoughton, 1985:8-23.

8 Widom CS. Does violence beget violence? A critical examination of the literature. Psychol Bull 1989;106:3-28.

9 Huesmann LR, Lagerspetz $K$, Eron LD. Intervening variables in the TV violence-aggression relation: evidence from two countries. Developmental Psychology 1984;20:746-75.

10 Eron LD. Interventions to mitigate the psychological effects of media violence on aggressive behavior. Fournal of Social Issues 1986;42:155-69.

11 Melville-Thomas G, Sims A. Psychiatrists' case studies. In: Barlow G, Hill A, eds. Video violence and children. London: Hodder and Stoughton, 1985:107-22.

12 Young Minds. Screen violence and child mental health. London: Young Minds, 1994.

13 Levine M. Vieving violence. New York: Doubleday (in press).

14 Buckingham D. Child's play. English and Media Magazine 1994;30:21-4.

15 Carlsson-Paige N, Levin DE. Making peace in violent times: a constructivist approach to conflict resolution. Young Children 1992:47:4-13.

\section{Bullying in schools: doctors' responsibilities}

\section{To ignore bullying is to condemn children to misery now and perhaps also in adult life}

Bullying is the intentional, unprovoked abuse of power by one or more children to inflict pain on or cause distress to another child on repeated occasions. It includes several different activities: hitting, pushing, spreading slanders, provoking, making threats, extortion, and robbery. A common, international phenomenon, it occurs to some extent in all schools. ${ }^{1-3}$ Whitney and Smith's study of more than 6000 pupils in 23 schools in Sheffield found that $27 \%$ of junior and middle school pupils and $10 \%$ of secondary school pupils said that they had been bullied sometimes or more often that term; $10 \%$ of junior and middle school pupils and $4 \%$ of secondary school pupils were being bullied at least once a week. ${ }^{3}$ Most had not told a teacher or anyone at home.

Bullying can be considered to be a form of child abuse: peer abuse. ${ }^{4}$ Like other forms of abuse, it is an abuse of power and is surrounded by fear, secrecy, and a misplaced loyalty to the perpetrator(s). Victims suffer adverse effects in the short and long term. Victims of regular bullying lack confidence, have lower self esteem, regard themselves as less competent, ${ }^{5}$ and have fewer close friends than children who are not bullied. ${ }^{25}$ Distress and preoccupation with their predicament may affect their concentration on their schoolwork. Bullying may be a contributory factor in why some children harm themselves or commit suicide, although this has not been systematically studied. When bullied children grow up they may be vulnerable to anxiety, depression, and loneliness (A $\mathrm{H} \mathrm{N}$ Gillessen, annual convention of American Psychological Association, 1992) ${ }^{2}$ and may have difficulties with heterosexual relationships. ${ }^{6}$ Because bullying is usually unseen teachers, parents, and other adults often underestimate its prevalence and effects.

Children who are bullied may be reluctant to attend school and may absent themselves. ${ }^{7}$ They may be presented to doctors with a variety of symptoms, including fits, faints, vomiting, limb pains, paralysis, hyperventilation, visual symptoms, headaches, stomachaches, fugue states, and 